\title{
The Sustainability of Art and Culture: The Malaysia Perspective
}

\author{
Wan Jamarul Imran Bin Wan Abdullah Thani \\ \{watimran@unimas.my\} \\ Universiti Malaysia Sarawak, Malaysia
}

\begin{abstract}
Art and culture are the core that serves as the identity, sign, and symbolism of the community, which becomes an important aspect for every community in shaping their culture. There is an important fact that the sustainability of art and culture able to contribute to the socio-economic and socio-cultural. However, the modernity, ecological development, and technological advances that are taking place, have challenge the continuity of art and cultural heritage. This paper focuses on identifying an appropriate approach and strategy for sustainable development of the art and cultural heritage in Malaysia. The need to ensure the sustainability of art and culture continues must be planned in detail and effectively. By understanding of the concept of sustainability, it can show value on focus and strategies for sustainability.
\end{abstract}

Keywords: Art and Culture, Sustainability, Cultural Heritage

\section{Introduction}

When it comes to art and culture, most people think that art and culture are the branches that lead to entertainment, but art and culture are more than that. Art and culture are two interrelated entities and dependent on each other. The scope of these two areas is very broad and complex, found also as if the two were inseparable from one another with others. It is considered the inseparable relationship. Art and culture are closely related to identity, ideology and the daily practice of a group of people. It is used to represent the core beliefs of a society. It is clear that art and culture reflect the lifestyle and thought patterns of the people in the surrounding area. Therefore, to understand a particular culture, we must look through its art that will reflect their activities and natural environment. All over the world, every society has its own artistic and cultural identity and therefore forms the uniqueness of their way of life [1]. In this context, arts seem becomes a culture, which exists as part of living and vehicle for social change.

The practice of art in society has formed a communication to help one to understand a culture. This has allowed people from different cultures and different times to communicate with each other via forms, images, sounds, and stories. Arts has become the cultural values, beliefs, and identities of the society or community. This situation has placed art as a form of traditional art that continues to be inherited. Indeed, in Malaysia, the multi-racial situation has created various artistic blends in the culture. But in this context, the emphasis has been on traditional arts among the indigenous communities. There is no denying that Malaysian traditional art is a partnership of the archipelago because it has similarities or commonality with the surrounding countries. As a cultural heritage, it is important to continue to preserve it for 
future generations. Yet the focus here is to see the continuation or sustainability of the arts that make up part of the culture, by exploring the true concept of sustainability [2].

Modernity is one of the factors that have an impact on the continuation of art and cultural heritage. Modernisation of culture through assimilation and adaptation of the modern living affected beliefs and customs the new generation of the community. Ecological changes also contribute to the factor, due to the purpose of national development, exploration and acquisition of settlements or areas that affect the arts, and cultural heritage of the locality. Another impact that changed and some extent affected the value of art and culture is the advancement of technology. The younger generation reluctant or lacks interest in continuing to master skill craftsmanship. No doubt we are living in the technological era and the advent of technology has simplified living and craftsmen skill. What we can see machine replaces the skill of craftsmen. Technological advances have commonly been the driving forces behind changes in daily practices, shifting the framework inside which human operate. Modernisation and technological advances that have taken place have led to adaptation and assimilation in art and culture. Therefore, methods through survey and environmental evaluation have helped to identify challenges and suggest strategy for sustainability.

\section{Arts as a Cultural Heritage}

Art is one aspect of culture. It is a very clear creative approach for artistic and aesthetic purposes to create objects or create concepts. It is a skill of craft in creating artistic and aesthetic objects. And to understand the cultural heritage is very subjective [3]. Heritage is related to something inherited from a person and a group of people from previous generations. Heritage describes the memory of the whole life of a nation and in turn symbolizes its civilization. In general, it builds the identity of the community that become a cultural heritage and is divided into two main categories, namely tangible culture heritage (intangible culture heritage) and intangible cultural heritage. Intangible cultural heritage is something that remains visible and can be held either static or mobile, while intangible cultural heritage is the opposite [4].

In Malaysia, arts and culture are protected by the 'National Heritage Act 2005', which under the Ministry of Tourism, Arts and Culture (MOTAC) and traditional art are placed under the 'intangible cultural heritage'. In 2020, MOTAC has gazetted 548 items as 'intangible heritage' under the National Heritage Act 2005. There are four categories, namely language and literature or verbal tradition, customs and culture, fine arts and craft arts, and performing arts [5]. Verbal tradition is in the form of poetry, folklore, advice, ballads, songs or proverbs. For custom and culture covered traditional games, martial art, and traditional customs. Performance art of the traditional performance such as mek mulung, mak yong, zapin, jikey, wayang kulit, ethnic dance and performance of Borneo, and many more. And, art craft including pottery or ceramics, labu sayung, batik, wood carvings, woven mats, woven songket, silver and gold embroidery, pua kumbu, headbands and woven fabrics, beads, production of copper, jewellery, and others.

UNESCO defines intangible cultural heritage as a practice, representation, expression, knowledge and skill that communities and groups recognise as part of their cultural heritage. It depends on those whose knowledge of traditions, skills and customs are passed on to the rest of the community, from generation to generation, or to other communities [4].

More focus should be given to enhance the role of art and culture in the lives of the people as well as to promote heritage and creative arts related industries. This concentration is due to the active involvement of all groups in art and cultural activities also contribute towards the 
development of individuals as a whole, strengthen national unity and improve the quality of life of the people. In this regard, more concerted efforts have been taken together to create better awareness and appreciation of the rich cultural heritage of the country. Awareness of the importance of heritage conservation efforts is a responsibility that must be borne by every individual in society. Therefore, heritage conservation efforts need to be done and take it seriously so that future generations have the opportunity to see and enjoy it in the future. Art heritage is able to describe the unique characteristics of a nation's cultural values. Art and cultural heritage is also able to give an image and identity to the appearance of the city and local culture [3].

\section{Supports and Efforts}

In order to succeed the sustainability, there must be a need for support. This involves funding allocations, strategic cooperation or collaboration, and ongoing efforts [6]. In Malaysia, the National Art Heritage Department under MOTAC plays an important role in looking into art and culture, including cultural heritage art. Apart from the government, support is also needed from local authorities, corporate agencies, art-based organisation, and art activists. Artbased organisations such as My Creative Venture/Cendana, Perak Art Foundation, Johor Heritage Foundation, and Sarawak Art Council are amongst the organisation supported by the government. A number of allocations are channelled through the government-supported organisation to assist efforts and activities towards the sustainability of art and culture. There are also corporate agencies that have come forward to fund and collaborate with the higher education research sector. Fund and collaboration are important as to run the activity and enhancing the art and cultural development. Efforts from all parties through activities such as organizing events, promotions and workshops involving arts and culture have been able to encourage and nurturing for the continuation of art and cultural values. It also preserving art and cultural heritage, so that it can be passed on to future generations.

\section{Benefits and Impacts of Sustainability}

Initiatives and incentives undertaken by government authorities as well as the national corporate sector have ensured the continuity of the art and cultural heritage. Specific planning is identified to ensure the achievement of mutual benefits taking into account the importance of preserving the traditional arts and cultural heritage of the community. From these efforts, sustainability has brought benefits in several aspects whether general or specific by contributing to socio-economic and socio-cultural.

In the socio-economy, it contributes to the economic growth of the country through the tourism industry. Activities to promote the tourism industry has encouraged infrastructure development and also create employment opportunities. This includes increased marketing of cultural heritage through the implementation of creative industry planning. Besides that, it generates a good value for living quality, especially for the rural community. It happens by providing training and management activities to improve the quality of life, which is able to reduce the poverty gap.

Several collaborative activities involving the government and corporate together with the research sector in educational institutions have been mobilized. For example, Universiti 
Malaysia Sarawak has undertaken several collaborative efforts with the Sarawak state government as well as combining efforts from other corporate sectors to see the sustainability of the arts and culture of the local ethnic community in Sarawak. Several arts and culture sustainability programs have been done to the community in rural areas such as Penan, Kelabit, Kayan, Kenyah and many more. These efforts have indirectly improved the socio-economy of the community.

In socio-cultural, it brought impact to self-growth and individual artistic values. Sustainability can improve self-growth, by boosting self-esteem, developing thinking skills, improving resilience and as well as enhancing confidence. It encourages lifelong learning and education. Also contributing to the self-talent, exhibiting artistic talent, and skill. This has to give the opportunity to feed creativity by nurturing creativity from hobby or interest. Thus boost creativity and imagination. It is part of reaching satisfaction by expressing emotion.

Besides that, here is another contribution relate to socio-cultural. It is on social well-being or therapeutic, whereby it promotes self-care and a near-meditative state. This brought into the activities that can contribute to mind-body well-being, which encouraging for a healthy society. However, the main contribution here is purposely to improve the public relationship. It contributes to the community and public engagement by bringing communities together or unites people. This process will allow of sharing experiences with others, regardless of their age, nationality, or religion. It is interesting to identify supporting vibrant communities. These can improve community relations, be a stimulant and self-stimulation

All gave a great impact on the country's economy, education, and society overall. Enriching and nourishing community well-being with better tolerance. Enhanced health and improve the quality of life for communities and individuals alike. It revitalising community on the aspects of the economy, social, environmental, and cultural [7].

\section{Strategy for the Sustainability}

In order to continue the sustainability, several focuses have been identified and outlined for implementation purposes. It takes into account the commitment of all parties by focusing on relationships and bridging the community. Here it is not just about the context of sustainability but the concept of sustainability. Context is to conserve and preserve, but concept is to deal with values of sustainability [2]. Focus on education, resources, development, appreciation, and awareness will be emphasised.

\subsection{Through Education}

Programs to educate and spread the importance of the appreciation of cultural, artistic and heritage values in society, especially the youth have been given a deeper emphasis. To achieve this goal, persistent measures have been taken to increase the number of people trained in various fields related to the arts and culture by the government as well as corporate agencies. Training and education programs are implemented by several institutions related to the field of arts. Indirectly it connects the art community with the education sector to support the development of heritage arts and culture. Strategic partnerships between governments, local authorities, the corporate sector and arts-based and community-based organizations have created a sustainable arts and cultural heritage. Various planned programs related to the 
appreciation of arts and heritage culture are also intensified and expanded by implementing several interactive programs involving community participation, especially youth.

\subsection{Creating Resources}

The economic potential of this creative culture industry must continue to be developed through close cooperation between various public and private sectors. To facilitate the development of this industry, the government has provided a conducive environment. The industry is encouraged to use various facilities at the state level such as state cultural centers and galleries to make their activities a success. In addition, the government has also provided suitable business premises to entrepreneurs to promote their heritage art and creative craft products. The promotion and marketing of art and cultural heritage products at the local and international levels are intensified through various marketing campaigns and the organization of interesting and prestigious international events. Malaysia which is in the archipelago environment has a wide source of arts and culture and there are similarities.

\subsection{Continuous Development}

In line with the aspiration to achieve excellence among professionals in the field of arts and culture. The arts and culture survival program continues to be implemented at relevant institutions as well as through various creative industry development programs to contribute to the development of technically skilled artists to face future challenges. There are special programs, such as apprenticeship schemes related to heritage and creative arts to provide skills as well as preserve heritage and creative arts in the traditional craft industry as well as modern crafts. If look at the institutions of higher learning, both the government and the private sector have also intensified skills training to produce quality professionals in the field of arts and culture. Ongoing efforts need to be taken to develop and improve the quality of heritage art and crafts. These efforts include conducting research and development on new methods to improve craftsmen skills as well as developing new designs and technologies in their production.

\subsection{Developing the Appreciation}

In addition, in-depth and up-to-date research on aspects of arts and culture has enabled an approach and conservation of arts and cultural heritage in a more consistent and integrated manner. Awareness and appreciation through current research will facilitate the continuity and the lasting of art and cultural heritage. To that end, researchers and institutions directly involved playing an important role by diversifying and expanding expertise in various fields related to arts and cultural heritage. Interestingly, with the development of information and communication technology, it has helped to document and develop the art and culture of heritage.

\subsection{Cultivate Awareness}

In order to foster appreciation among the younger generation, there must be an awareness of the arts and cultural heritage. In line with this, various programs are implemented to increase the appreciation of art and culture among the people at all levels as an effort to create a society rich in cultural heritage. In this regard, activities related to arts and culture have been implemented in a planned manner at the national, state, district and village levels. It aims to 
spread awareness and appreciation of arts, culture and heritage among more Malaysians. Expand the need for a good resource center to students, researchers, academics, craft entrepreneurs and those directly or indirectly involved.

\section{Conclusion}

The transitions and changes of the modern way of life will leave a greater impact on the loss, neglect, extinction and destruction of art and cultural heritage. By controlling for change through sustainability strategies will make the next generation of young people have a strong cultural awareness of arts and cultural heritage. A better appreciation of art and cultural heritage among the community, access to the activities should be increased while the active involvement of all communities must be encouraged.

This sustainability contributes to many things involving the improvement of the sociocultural and socio-economic quality of the country and society. Indeed, art and cultural heritage can be among the formulas of the country's success now and in the future. It serves as part of the basis for shaping the community's values on identity, beliefs, and traditions. Strategies identified are not only able to ensure sustainability through conservation and preservation but apply sustainability through deeper values. Several approaches taken by the government as well as corporate sector or private organisation has assisted to ensure sustainability. There is no denying that art and culture are considered as an attraction for tourism purposes. Seen many destinations make art and cultural heritage as a promotion. Judging from this, many benefits are obtained through the sustainability of art and culture. All the adaptation and assimilation have made an impact on art and culture.

\section{References}

[1] M. Vecco, "A definition of cultural heritage: From the tangible to the intangible," J. Cult. Herit., vol. 11, no. 3, pp. 321-324, 2010.

[2] S. Kagan and V. Kirchberg, higher education for sustainability Sustainability: a new frontier for the arts and cultures. 2008.

[3] M. Y. M. Yusoff, "Pemulihan Warisan Budaya Melalui Perundangan Warisan dan Agensi Pelaksana di Malaysia," J. Melayu Univ. Kebangs. Malaysia, vol. 17, no. 2, pp. 143-159, 2018.

[4] UNESCO, "What is Intangible Cultural Heritage?," 2020.

[5] S. N. Harun, "Heritage building conservation in Malaysia: Experience and challenges," in Procedia Engineering, 2011, vol. 20, pp. 41-53.

[6] F. Nocca, "The role of cultural heritage in sustainable development: Multidimensional indicators as decision-making tool," Sustain., vol. 9, no. 10, Oct. 2017.

[7] A. Kay, "Art and community development: The role the arts have in regenerating communities," Community Dev. J., vol. 35, no. 4, pp. 414-424, 2000. 